I europeisk skjønnlitteratur fra kolonitiden var det vanlig å skildre orientalere på samme måte som man skildret kvinner

- som enkle og irrasjonelle, barnlige, nært knyttet til naturen - kort sagt, underlegne.

\title{
Orientalisme og kjønn
}

Sigrid Briseid er idéhistoriker, og jobber for tiden som lektor ved Lillestrøm videregående skole. 
TEKST: Sigrid Briseid

ORIENTEN BLE GJERNE fremstilt som et erotisk drømmested for menn - et friområde der mannlige europeere kunne boltre seg i uforpliktende orientalsk sex.

I «Orientalisme: Vestlige oppfatninger av Orienten» fra 1978 peker Edward W. Said på en rekke tradisjonelle forestillinger om Orienten og argumenterer for at disse har vært med på å legitimere kolonialismen. Han hevder også at orientalismen er et uttrykk for en mannlig verdensanskuelse. Orientalismen var, ifølge Said, så mektig at den satte grenser for tankene og handlingene til alle som skrev om Orienten. Said har med andre ord skrevet historien om Orienten som en tankeretning, nært knyttet til politikk og makt.

Min påstand er at uten å se på orientalisme som en tankeretning, er det umulig å fatte den enormt systematiske disiplin som gjorde europeisk kultur i stand til å styre - og endog fremstille - Orienten politisk, sosiologisk, militort, ideologisk, vitenskapelig og imaginoert $i$ perioden etter opplysningstiden. Dessuten har orientalismen hatt en så overveldende posisjon at jeg ikke tror noen har kunnet skrive, tenke eller foreta seg noe om Orienten, uten å ta hensyn til de begrensninger orientalisme har satt for tanke og handling. ${ }^{1}$

Orientalismen var en overordnet ramme som alle europeere i imperialismens tidsalder skrev, tenkte og handlet innenfor. Europeisk skjønnlitteratur med handling fra koloniene bidro til å legitimere kolonialismen ved å gi næring til europeeres forestillinger om at "vi" europeere var egnet til å dominere, veilede og lære opp "de andre".

\section{Den sensuelle og feminine Orienten}

Det var ikke uvanlig å fremstille orientalerne som passive kvinner uten evne til intellektuell tenkning. ${ }^{2}$ Orienten var, for mange europeere, et fristed fra normer, regler og tabuer som eksisterte i hjemlandet, et sted der europeiske menn fikk utløp for sine undertrykte lengsler.

Dette kommer tydelig til uttrykk i reiseskildringer og skjønnlitteratur med handling fra Orienten. Forfatteren André Gide beskriver for eksempel mellom linjene en forkjærlighet for unge gutter i boken «L' Immoraliste». Hovedpersonen i denne boken opplever en forvandling i møtet med Orienten, akademikeren orker knapt å tenke, og i hvert fall ikke å forske: “Når sant skal sies, tenkte jeg ikke, jeg reflekterte ikke over hva jeg selv gjorde, men lot meg lede av en lykkelig skjebnetro." ${ }^{3}$ At Orienten har en slik innvirkning på folk, er 
et klassisk tema i eksotisk litteratur, Orienten blir ofte assosiert med det irrasjonelle, les: kvinnelige. Videre var orientalismen i seg selv et område utelukkende for menn; som så mange yrkesgrupper i moderne tid, betraktet den seg selv og sitt emne gjennom kjønnsfikserte skylapper. Dette er særlig merkbart i skrivingen til reisende og romanforfattere: kvinner er vanligvis vesener i mannlige fantasier om makt. De uttrykker grenseløs sensualitet, de er mer eller mindre dumme, men mest av alt er de villige. $^{4}$

Orienten er tradisjonelt blitt forbundet med noe sensuelt, en forestilling man finner igjen hos mange forfattere og malere på ı8oo-tallet. I sin omtale av den franske forfatteren Gustave Flaubert skriver Said: "Innvevd i alle Flauberts orientalske opplevelser, enten de nå var spennende eller skuffende, er en nærmest unyansert forbindelse mellom Orienten og sex." 5

Det synes å ha vært en utbredt oppfatning at orientalere var spesielt lidenskapelige, at de var i besittelse av en utrettelig sensualitet. Mange av de europeiske forfattere som reiste til Orienten på ı8ootallet, var på utkikk etter en seksuell erfaring som de ikke fikk i Europa - “orientalsk sex" var faktisk et begrep. Emile Zolas romanskikkelse Thérése Raquin fremstilles som en usedvanlig lidenskapelig kvinne, og forklaringen ligger i hennes orientalske aner, moren var fra Alger:

Ved første kyss viste hun seg å vare skapt for elskov. [...] Alle hennes nervøse instinkter våknet med en utrolig intensitet; hennes mors blod, det afrikanske blodet som brant $i$ årene hennes, tok til å strømme hett og brusende $i$ den magre kroppen som ennå var så à si uberørt. Hun åpnet seg, hun bød seg frem med suveren skamløshet. ${ }^{6}$

Zolas romanskikkelse representerer det pirrende forbudte - motsatsen til moralens og fornuftens Europa, og dette er et gjennomgangstema i europeisk litteratur fra kolonitiden. Litteraturens orientalske kvinner er ikke nødvendigvis like skamløse som Zolas romanskikkelse. Hun finnes i mange varianter, ofte blir hun skildret som et naivt og uskyldig barn med behov for veiledning av en fornuftig europeisk mann. De sensuelle undertonene er imidlertid som regel tilstede, og den mytiske orientaleren er i svært mange tilfeller et objekt for mannlige reisendes fantasier.

\section{Kvinnelige forfattere i Orienten}

De fleste reisende og forfattere i samtiden var menn, men også hos kvinnelige forfattere fra kolonitiden kan man finne lignende forestillinger om mennesker fra det halvmytiske Orienten. Et eksempel er forfatteren og journalisten Isabelle Eberhardt (I877- I904), som reiste mye i det franskkoloniserte Nord-Afrika og bosatte seg i Algerie.? Hun hadde bedre kjennskap til den opprinnelige befolkningen enn europeere flest, snakket arabisk, lot seg omvende til islam og var kritisk til det franske nærææret i Nord-Afrika. Likevel er hennes skjønnlitterære fremstillinger av den nordafrikanske befolkningen forbausende romantiske, idealiserte og stereotype.

Eberhardts litterære forgjengere og forbilder var stort sett menn. Som kvinne var hun nokså alene, selv i de radikale journalistmiljøene i Nord-Afrika. Mange regner henne som den første kvinnelige krigsreporter noensinne. Isabelle Eberhardt var på 
mange måter en spesiell skikkelse. Kledd som mann opererte hun ofte under det arabiske pseudonymet Mahmoud Saadi, og ble til og med tatt opp som bror i et sufibrorskap. ${ }^{8}$ Flere har også hevdet at hun skrev som en mann fordi hun benyttet seg av de samme litterære grepene som sine mannlige forgjengere. ${ }^{9}$

Eberhardts ideer om den orientalske kvinnen er til tider like stereotype som andres, for eksempel når hun fremstiller beduinerjenter i den nordafrikanske ørkenen. Den lille berberjenta Yasmina i novellen med samme navn, lever et fredelig liv som sauegjeter på de algeriske slettene inntil den dagen hun møter en fransk løytnant, noe som fører til hennes ulykke. Hun fremstilles av Eberhardt tidstypisk nok som et naivt, men sexy barn: "Den berberske rases store sorte øyne skinte mystisk, deres mørke og triste uttrykk stod i merkelig kontrast til konturene av de litt tykke og blodfulle leppene som var både sensuelle og barnlige på én gang." 음

Det florerer av slike beskrivelser i Isabelle Eberhardts skjønnlitteratur, spesielt i de tidligste tekstene hennes. Hun var åpenbart svært påvirket av den franske orientalismen, det kommer frem både $\mathrm{i}$ språkbruk, dramaturgi og valg av skikkelser og tema. Ørkenbeduiner og sensuelle prostituerte kvinner befolker mye av den orientalistiske litteraturen - i likhet med Eberhardts skjønnlitterære noveller. Hun var dermed med på å videreformidle en rekke gjengse oppfatninger av Orienten, forbundet med det kvinnelige, sensuelle og irrasjonelle.

Eberhardt evnet imidlertid samtidig å skildre den dominerende ideologien med en viss kritisk distanse, hun fremstiller nemlig den franske kolonialismen i Algerie som moralsk problematisk. Dette var hun riktignok ikke alene om, mange europeiske intellektuelle som reiste i koloniene hadde et ambivalent forhold til det europeiske nærværet $i$ de områdene de reiste $i$, samtidig som de opplevde møtet med det fremmede som enormt fascinerende. Eberhardt var kvinne, og det kan ha bidratt til en økt forståelse for “de innfødtes” sak. Det er blitt hevdet at kvinnelige forfattere fra kolonitiden som regel viste større sympati med den undertrykte opprinnelige befolkningen, noe som kan ha sammenheng med at europeiske kvinner ble undertrykt av menn. ${ }^{\text {II }}$

Men Isabelle Eberhardt var ingen tradisjonell kvinne. Mer enn å være kvinne var

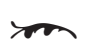

Det var ikke uvanlig å fremstille orientalerne som passive kvinner uten evne til intellektuell tenkning.

hun en utenforstående - en kvinne i mannsklær som ikke følte seg hjemme i Europa og nærmest flyktet til Nord-Afrika for å starte på nytt. Eberhardt fikk etter hvert førstehånds kjennskap til samfunnet i de områdene hun reiste $i$, og hun engasjerte seg i muslimenes sak gjennom sine skarpt samfunnskritiske artikler. Likevel forble fiksjonen hennes tydelig lenket til en imperialistisk og maskulin diskurs språket, stilen, idéverdenen viser det. Samtidig er mye av det Eberhardt skrev også en kritikk av denne, og et forsøk på å stille opp et alternativ.

Isabelle Eberhardt var ikke en overfladisk reisende som skrev banalt og kunnskapsløst om “de andre”. Hun gjorde 
et ærlig forsøk på å bli en del av en annen kultur og brukte mye spalteplass på å forsvare den opprinnelige befolkningen i Algerie mot kolonimaktens overgrep. Men hun klarte ikke helt å løsrive seg fra kolonimaktens språk - hun var og ble et barn av sin tid og rakk heller ikke å bli en moden forfatter. Da hun var 27 år gammel, døde hun i en flom i den algeriske ørkenbyen A' $n$ Sefra. Tekstene hennes er imidlertid interessante - ikke minst fordi en kan spore et forsøk på å løsrive seg fra disse rammene som vi - takket være Edward Said - er blitt så flinke til å se og sette ord på. Men å analysere Isabelle Eberhardts tekster ut fra et tradisjonelt Said-perspektiv er ikke nødvendigvis det mest fruktbare. Det er fare for at det interessante og spesielle ved tekstene til en reisende som henne vil drukne $i$ en opplest og vedtatt holdning om at alle europeere per definisjon var imperialister. Isabelle Eberhardt er nok mer interessant som kritiker enn som imperialist.

\section{Orientalisme i dag}

Mange mener Saids kritikk av orientalisme er for grovmasket. Hans perspektiver er derfor blitt videreutviklet og nyansert. John Mackenzie, som har nærlest britisk skjønnlitteratur fra kolonitiden, mener for eksempel det er umulig å gjenkjenne den fastfrosne binære opposisjonen mellom “oss selv" og "de andre" som Said mener å finne i tekster fra kolonitiden. ${ }^{\mathrm{I} 2}$ Said er blitt kritisert for å være inkonsekvent, repetitativ og svart-hvitt-tenkende. Han er blant annet blitt beskyldt for å fremstille europeiske aktører like stereotypt som han hevder "orientalerne” ble beskrevet. Like fullt kommer ingen av kritikerne utenom ham. Han har gitt oss en fortolkningsnøkkel som gjør det mulig å avdekke imperialismens maktstrukturer. Disse mekanismene kan, som nevnt, synes åpenbare når tekster fra I8ooog tidlig I900-tallet dissekeres. Det er vanskeligere å avdekke dem i dagens politikk, kunst og vitenskap.

Said selv brukte mye tid og krefter på å påvise orientalismens strukturer $\mathrm{i}$ dagens amerikanske politikk og medier. ${ }^{\mathrm{I3}}$ Han skrev ukentlige artikler i amerikanske aviser om konflikten mellom israelere og palestinere. Han var krass og vanskelig å akseptere for mange - ikke minst vakte det oppsikt da han kastet stein mot israelerne, riktignok på trygg avstand. Han var omstridt i jødiske kretser i USA - han holdt på å miste stillingen som professor ved Columbia-universitetet i New York men også i den arabiske verden. Said kritiserte Arafat og Oslo-prosessen. Bøkene hans ble faktisk forbudt på de okkuperte områdene, til tross for at han var palestinernes viktigste gallionsfigur blant vestlige akademikere.

Helt til det siste skrev Edward Said illsinte debattinnlegg om den aktuelle politiske situasjonen i Midtøsten. Han uttrykte sterk bekymring for det hardere politiske klimaet i USA etter II. september 200I som han beskrev som et apokalyptisk utslag av det skrekkelige fenomenet selvmordsbombere. Han var nådeløs i sin kritikk av den britisk-amerikanske invasjonen i Irak:

Den hardere ideologiske tonen, den økte bruken av nedvurderende generaliseringer og seierherreklisjeer, den rå maktens dominans kombinert med forakt for dissidenter og "andre" i USA fant sitt passende motstykke $i$ plyndringen og ødeleggelsen av Iraks museer og biblioteker. Det våre ledere og deres intellek- 
tuelle lakeier synes å vare ute av stand til a forstå, er at historien ikke kan viskes ut som skriften på en tavle, gjøres ren slik at "vi" kan skrive inn vår fremtid der og tvinge igjennom våre måter å leve på overfor disse mindreverdige folkene. ${ }^{14}$

Dette sitatet er hentet fra en artikkel skrevet rett før han døde, i forbindelse med 25-årsjubileet for utgivelsen av «Orientalisme». Slik demonstrerte den dødssyke Said selv at bokas perspektiver kanskje er mer aktuelle enn noensinne. Edward W. Said døde etter langvarig sykdom den 24. september 2003.

\section{- $f \cdot$}

I Edward W. Said: «Orientalisme: vestlige oppfatninger av Orienten», Cappelen, Oslo I994 s. I3.

2 Sara Mills: «Discourses of Difference An Analysis of Women's Travel Writing and Colonialism», London,

$\mathrm{R}$ ledge I99I $\stackrel{\text { s. } 92 .}{2}$

3 André Gide: «L'immoraliste», Paris, Mercure de France: I962 s. 60.

4 Edward Said: «Orientalisme» S. 228.

5 Edward W. Said: «Orientalisme» s. 208.

6 Emile Zola: «Thérése Raquin», oversatt av Anne Elligers, Oslo, Den norske Bokklubben: 1989 s. 44.

7 Mye er skrevet om Isabelle Eberhardt på fransk og engelsk. Det meste er biografisk, men tekstene hennes er oversatt til engelsk og svensk. På norsk finnes min hovedoppgave i idéhistorie «Isabelle Eberhardt og Orienten», UiO 200I samt artikkelen "Isabelle Eberhardt og flukten fra

$\mathrm{T}$ samtiden" i Arr - idéhistorisk tidsskrift nr. 3 200I. $\begin{array}{ccccr}\mathrm{o} & \mathrm{r} & \mathrm{u} & \mathrm{n} & \mathrm{n} \\ \text { Borge har dessuten } & \text { skrevet en artikkel om henne i Vin- }\end{array}$ duet 2000. Eberhardt er også representert med en tekst i antologien «Yrke - reporter», Oktober I999.

8 Sufismen er den islamske mystikken. Isabelle Eberhardt var medlem av et Quadiriya-brorskap, en form for sufisme som stod sterkt i de nordafrikanske koloniene, og som også hadde en viss betydning i kampen for frigiøringen fra kolonimakten Frankrike.

9 Daniéle Masse: «Deux itinéraires sous le signe de l'Orient: Isabelle Eberhardt et Ella Maillart», doktoravhandling fra Université d'Aix-Marseille I, I990-9I s. 362.

Io Novellen er å finne i flere ulike tekstsamlinger både på fransk og engelsk. Den finnes kun på norsk i min hoved- oppgave i idéhistorie: «Isabelle Eberhardt og Orienten», $\mathrm{UiO} 200 \mathrm{I}$.

II Reina Lewis: «Gendering Orientalism: Race, Feminity and Representation» S. I5.

I2 John MacKenzie: "History, Theory and the Arts" $\mathrm{i}$ «Orientalism - A reader» S. 332.

I3 Han har blant annet skrevet «Covering Islam: how the media and the experts determine how we see the rest of the world», London I98I.

I4 Edward W. Said: "Humanisme eller barbari", trykket i anledning 25 -årsjubileet for utgivelsen av «Orientalisme», Le monde diplomatique (nordisk utgave) den I/9- 2003 . 